\title{
1. Beyond inflation targeting: assessing the impacts and policy alternatives
}

\section{Gerald Epstein and A. Erinç Yeldan'}

\subsection{INTRODUCTION}

lnflation targeting (IT) is the new orthodoxy of mainstream macroeconomic thought. The approach has now been adopted by 24 central banks, and many more, including those in developing countries, are expressing serious interest in following suit. Initially adopted by New Zealand in 1990, the norms surrounding the IT regime have been so powerful that the central banks of both the industrialized and the developing cconomies alike have declared that maintaining price stability at the lowest possible rate of inflation is their only mandatc. It was generally believed that price stability is a pre-condition for sustained growth and cmployment, and that 'high' inflation is damaging the economy in the long run.

In broad terms, the IT policy framework involves 'the public announcement of inflation targets, coupled with a credible and accountable commitment on the part of government policy authorities to the achievement of these targets' (Setterfield, 2006, p.653). As advocated, 'full lledged' inflation targeting consists of five components: absence of other nominal anchors, such as exchange rates or nominal GDP; an institutional commitment to price stability; absence of fiscal dominance; policy (instrument) independence; and policy transparency and accountability (Bernanke et al., 1999; Mishkin and Schmisit-Hebbel, 2001, p. 3). In practice, while few central banks reach the 'ideal' of being 'full fledged' inflation targeters, many others still focus on fighting inflation to the virtual exclusion of other goals.

For its proponents, the appropriate inflation target is typically prescribed as maintaining price stability, though there is less agreement on the meaning of this term and on its precisc measurement. Many praclitioners simply atopt the widely cited definition of Alan Greenspan, the former Governor of the US Fed, issued at the July 1996 meeting of the Federal Open Market Committee, as 'a rate of inflation that is sufficiently low that households and businesses do not have to take it into account in 
making every day decisions'. For Feldstein (1997), however, price stability meant a longrun inflation ratc of zero. In addition, IT is usually associated with appropriate changes in the central bank law that enhances the independence of the institution (Bernanke et al., 1999, p. 102; Mishkin and Schmidt-Hebbel, 2001, p. 8; see also Buiter, 2006 for an evaluation). Note that this promotion of central bank independence often is inconsistent with the above mentioned commitment to accountability, if by accountability, onc means democratic accountability.

Ironically, employment creation has dropped ofl the direct agenda of most central banks just as the problems of global unemployment, underemployment and poverty are taking center stage as critical world issues (Heintz, 2006). The International Labour Organization (ILO) estimates that in 2003 approximately 186 million people were jobless, the highest level ever recorded (ILO, 2004a). The employment to population ratio - a measure of unemployment - has falten in the last decade, from 63.3 percent to 62.5 percent (ILO, 2004). And as the cluantity of jobs relative to need has fallen, there is also a significant global problem with respect to the quality of jobs. The ILO estimates that 22 percent of the developing world's workers earn less than $\$ 1$ a day and 1.4 billion (or 57 percent of the developing world's workers) earn less than $\$ 2$ a day. To reach the Millennium Development Goal of halving the share of working poor by 2015, sustained, robust economic growth will be required. The ILO estimates that on average, real GDP growth has to be maintained at 4.7 percent per year to reduce the share of $\$$ I a day poverty by half by 2015 , and signilicantly more than that to reduce the share of $\$ 2$ a day poverty by half.

Moreover, China's and India's opening up to the global markets and the collapse of the Soviet system together have added 1.5 billion new workers to the world's economically active population (Frceman, 2004, 2005; Akyuz, 2006). This means almost a doubling of the global labor force and a reduction of the global capital-labor ratio by half. Concomitant with the emergence of the devcloping countries in the global manufacturing trade, about 90 percent of the labor employed in world merchandise trade is low skilled and unskilled, suffering from marginalization and all too frequent violation of basic worker rights in informalized markets (see, for example, A kyuz, 2003, 2006; A kyuz et al., 2006).

Under these conditions, a farge number of developing countries have suffered de-industrialization, serious informalization and conseguent worsening of the position of wage-labor, resulting in a deterioration of income distribution and increased poverty. Many of these phenomena have occurred in tandem with the onset of neoliberal conditionalities ${ }^{2}$ imposing rapid liberalization of trade and premature deregulation of the indigenous linancial markets. 
The key problem is that the ongoing 'linancial globalization' appears primarily to redistribute shrinking investment funds and limited jobs across countries, rather than to accelerate capital accumulation across a global scalde (Adelman and Yeldan, 2000; Akyuz, 2006). Simply put, the world economy is growing too slowly to generate sulficient jobs and it is allocating a smaller proportion of its income to fixed capital formation. In addition, asset price bubbles and crashes, with their attendant financial fall-out are plaguing the system. Under thesc conditions, it ought to be clear that price stability, on its own, will not sullice to maintain macroeconomi: stability, as it cannot suflice to secure financial stability and employment growth. In the words of Akyuz (2006, p. 46), 'the source' of' macroeconomic instubility now is not instability in product markets but asset markets, and the main challenge for policy makers is not inflation, but unemployment and finuncial instability' (emphasis added).

Yet, surprisingly, despite al disalppointing record, this almost single minded focus on commodity inflation is gaining a more secure foothold in monetary policy circles and the circles are widening to include an increasing number of developing countries. According to a recent report by the Intcrnational Monetary Fund (IMF), an increasing number of central banks in emerging markets are planning to adopt IT as their operating framework (13atini et al., 2006; Table 1.1). An IMF stail survey of 88 non-industrial countries found that more than half expressed a desire to move to explicit or implicit quantitative inflation targets. More relevant to our concerns, nearly threequarters of these countrics expressed an interest in moving to 'full--lledged' IT by 2010. To support and encourage this movement, the IMF is providing technical assistance to many of these countries and is willing to provide more (Table 1.1 and further discussion below). In addition, the IMF is considering altering its conditionality and monitoring structures to include inflation targets. In short, despite little evidence concerning the success of IT in its promotion of economic growth, employment creation and poverty reduction, and mixed evidence at best that it actually reduces inflation itself, a substantial momentum is building up for full-fledged IT in developing countries. Promotion efforts by the IMF and Western-trained economists are at least partly responsible for this increasing popularity.

While it might seem obvious that stabilization focused monetary policy represents the only proper role for centra! banks, in lact looking at history casts serious doubt on this claim. Far from being the historical norm, in many of the successful currently developed countries, as well as in many developing countries in the post-Second World War period, pursuing development objectives was seen as a crucial part of the central banks' tasks (Epstcin, 2007). Now, by contrast, development has dropped off the policy agenda of central banks in most developing countrics. 
Table 1.1 Inflation targeting countries: initial conditions and modalities:

\begin{tabular}{|c|c|c|c|c|}
\hline $\begin{array}{l}\text { Developing countrics } \\
\text { (in order of adoption) }\end{array}$ & $\begin{array}{c}\text { IT } \\
\text { adoption } \\
\text { datc }\end{array}$ & $\begin{array}{l}\text { Inflation } \\
\text { ratc at } \\
\text { start } \\
\text { ("\%/ per } \\
\text { annum) }\end{array}$ & $\begin{array}{c}\text { Current } \\
\text { inflation } \\
\text { target } \\
\text { (' } / 4 \text { per } \\
\text { annum) }\end{array}$ & $\begin{array}{l}\text { Officially } \\
\text { declared } \\
\text { policy } \\
\text { instrument }\end{array}$ \\
\hline Israel & 1997Q2 & 8.5 & $1-3$ & $\begin{array}{l}\text { headline } \mathrm{O} / \mathrm{N} \\
\text { rate }\end{array}$ \\
\hline Czech Rep. & 1998Q1 & 13.1 & $3(+1-1)$ & 2 week repo \\
\hline Poland & 1998Q4 & 9.9 & $2.5(+1-i)$ & $\begin{array}{l}28 \text { daly } \\
\text { intervention }\end{array}$ \\
\hline Brazil & 1999Q2 & 3.3 & $4.5(+12)$ & sclic $\mathrm{O} / \mathrm{N}$ rate \\
\hline Chile & 1999Q3 & 2.9 & 24 & O/N rate \\
\hline Colombia & 1999Q3 & 9.3 & $5(+1-0.5)$ & repo \\
\hline South Africal & 2000Q1 & 2.3 & $3-6$ & \\
\hline Thailand & 2000Q2 & 1.7 & $0-3.5$ & 14 day repo \\
\hline Korea & 2001QI & 3.2 & $2.5-3.5$ & $\mathrm{O} / \mathrm{N}$ call rate \\
\hline Mexico & 2001QI & 8.1 & $3(+1-1)$ & 91-day Cetes \\
\hline Hungary & $2001 \mathrm{Q} 2$ & 10.5 & $3.5(+1-1)$ & 2 week deposil \\
\hline Peru & 2002QI & -0.8 & $2.5(+1-1)$ & \\
\hline The Philippines & 2002QI & 3.8 & $5-6$ & reverse repo \\
\hline Slovak Republic & 2005QI & 3.2 & $3.5(+1-1)$ & \\
\hline Indonesia & $2005 Q 3$ & 7.8 & $5.5(+/ 1)$ & I-month SBI \\
\hline Romania & 2005Q3 & 8.8 & $7.5(+1-1)$ & \\
\hline Turkcy" & 2006QI & 7.8 & $5(+1-2)$ & CB O/N rate \\
\hline Turkey" & 2001Q2 & 82.0 & n. a & $\begin{array}{l}\text { CB net } \\
\text { domestic assets }\end{array}$ \\
\hline \multicolumn{5}{|l|}{ Industrial Countrics } \\
\hline New Zealand & $1990 Q 1$ & 7.0 & $1-3$ & cash rate \\
\hline Canada & $1991 \mathrm{Q}$ & 6.2 & $1-3$ & $\begin{array}{l}\text { O/N lunding } \\
\text { ralte }\end{array}$ \\
\hline United Kingdom & $1992 \mathrm{Q} 4$ & 3.6 & 2 & repo \\
\hline Sweden & 1993QI & 4.8 & $2(+1-1)$ & геро \\
\hline Australia & 1993Q2 & 1.9 & $2-3$ & cashl rate \\
\hline Iceland & 2001QI & 3.9 & 2.5 & \\
\hline Norway & 2001QI & 3.7 & 2.5 & \\
\hline
\end{tabular}

Candidate Countries

Costa Rici.

Ukraine

Near Term

Albania. Armenia, (12 years)

Botswana, Term (3-5

Dominican years\} 
Tuble 1.1 (continued)

Rep., Gutcmala,

Mauritius, Uganda,

Angola, Azerbaijan,

Georgial, Moldova.

Serbia, Sri Lanka,

Vielnam, Zambia

$$
\begin{gathered}
\text { Term } \\
\text { (3-5 years) }
\end{gathered}
$$

Meditum

Belarus, China,

Kenyal, Kyrgyz Rep.,

Moldova, Serbia,

Sri Lankal, Vietnam,

Zàmbia

Long Term

Bolivia, Honduras,

Nigeria, Papua New

(>5 yealss)

Guinea, Sudan,

Tunisia, Urugualy,

Venezucla

Notes:

i. Official adoption date for Turkey.

b. Turkish central batnk declared 'disguised inftation targeting' in the aftermath of the 2001 February crisis.

Sonrce: Battinj co al. (2006)

The theme of this book is that modern central banking ought to have more policy space in balancing out various objectives and instruments. In particular, employment creation, poverty reduction and more rapid economic growth should join infation stabilization and stabilization more generally as key goals of centra! bank policy. In introducing this volume, this chapters outlines why a shift away from 1T, the increasingly fashionable, but problematic approach to central bank policies, and a move toward a more balanced approach is both desirable and feasible.

The rest of the chapter is organized as follows. In the next section, we briefly survey the macroeconomic record of IT and its current structure. Section !.3 focuses on the role of the exchange rate as one of the key macro prices, and discusses alternative theories of its determination. We also make remarks on the issue of IT in the context of the so-called 'trilemma' of monetary policy. In Section I .4 we discuss various alternatives to infiation focused central banks, concentrating on the rcsults of a multi-country research project undertaken with the support of UN-DESA, among other organizations. This section shows that there are viable, socially productive 
alternatives to IT, including those that focus on employment generation, and makes the case that these alternatives should be further developed. Section 4.5 concludes the chapter.

\subsection{MACROECONOMIC RECORD OF INFLATION TARGETING}

Much of the existing literature on the record of IT has focused mostly on whether systemic risksand accompanying volatility has been reduced in the IT economies, and whether inflation has come down actually in response to adoption of the framework itsclf or due to a set of 'exogenously welcome' lactors. On the one side, there is a fair amount of agreement that IT has been associated with reductions in inflation. Furthermore, exchange rate pass-through eflects were reportedly reduced and consumer prices have become less prone to shocks (Edwards, 2005; Mishkin and SchmidtHebbel, 2001). Yet existing evidence also suggests that IT hats not yielded inflation below the levels attained by the industrial non-targeters that have adopted other monetary regimes (Ball and Sheridan, 2003; Mishkin and Scmidt-Hcbbel, 2001; Roger and Stone, 2005). Moreover, even if domestic monetary policy has reduced inflation, the hoped for gains in economic growth and employment have, generally, not materialized.

On the 'qualitative' policy front, it is generally argued that with the onset of central bank independence, communication and transparency have improved and that the central banks have become more 'accountable'. Yet in practice, 'central bank independence' means that central banks have become less accountable to their governments, and, arguably, more accountable to financial elites and international organizations such as the IMF.

Moreover, little is known about the true costs of IT on potential output growth, employment, and on incidence of poverty and income distribution. Bernanke et al. (1999) and Epstein (2007), for instance, report evidence that IT central banks do not reduce inflation at any lower cost than other countries" central banks in terms of foregone output. That is, IT does not appear to increase the credibility of central bank policy and thercfore does not appear to reduce the sacrilice ratiog. Per contra, based on an econometric study of a large sample of inflation targeters and nontargeters, Corbo et al. (200I) concluded that sacrifice ratios have declined in the emerging market economies after adoption of IT. They also report that output volatility has fallen in both emerging and industrialized economies after adopting IT. This position is recently complemented by a study of the IMF economists, who, using a complex cconometric model 
and policy simulations, report lindings that inflation targeting economies expericnce reductions in the volatility in inflation, without experiencing increased volatility in real variables such as real GDP (Batini et al., 2006). According to these estimates, IT central banks do enhance economic 'stability' relative to other monetary rules, such as pegged exchange rates and monetary rules.

However, in the assessments of 'stability', these papers do not consider the issue of the stability of asset prices, inciuding exchange rates, stock prices and other financial asset prices/As we discuss farther below, asset price stability may need to be included in a full analysis of the impact of IT on overall economic stability. Asset price stability aside, while intriguing, these results are only as strong as the simulation model on which they are based and are only as relevant as the relevance of the questions they pose. Moreover, they are only as broad as the alternatives they explore. On all these scores, these results are problematic. First, they do not simulate the impact of IT relative to other possible policy regimes, such as targeting the real exchange rate as discussed below. Second the model is based on estimates of potential output that are themselves affiected by monetary policy (see, for example, Michl, 2007; Tobin, 1980). Hence, if monetary policy slows economic growth, it also lowers the rate of growth of potential output and, therefore, reduces the gap between the two, thereby appearing to stabilize the economy.

Ecually, if not more important, is the practical problematigue of setting the largeted rate of inflation itself. Even if the advocaled recpuisites of the IT regime are taken for granted, it is not yet clear what the practically targeted rate of infation should be. Even though there appears to be a consensus among the advocates of the IT regime that the inflation target has to be 'as low as possible', there is no theoretical justification of this assertion; and as such, il sounds more of a recommendation than a careful calculation. Most disturbing is the common belief that what is good for the industrialized/developed market economies should simply be replicated by the developing countries as well. That this may not be the case is lorcefully argued in Pollin and Zhu (2006). Based on their non-linear regression estimates of the relationship between inllation and economic growth for 80 countries over the period 196 1-2000, Pollin and Zhu report that higher inflation is associated with moderate gains in GDP growth up to a roughly $15-18$ percent inflation threshold. Furthermore they report that there is no justification for IT policies as they are currently being practiced throughout the middle and low-income countries, that is, to maintain inflation with a 2-4 percent band.

Moreover, we have other evidence on the negative consequences of monetary policy designed to produce extremely low levels of inflation in 
developing countries. Braunstein and Heintz show that contractionary monetary policy used to fight inllation of ten has a differentially negative impact on the employment rates of women relative to men (Braunstcin and Heintz, Chapter 5, this volume). Given the possible negative costs of IT on output and employment, there should be some direct survey cvidence indicating people's preferences with respect to inflation and unemployment. While some studies have indicated that people have an absolute preference for low inflation, Arjun Jayadev (Chapter 4, this volume) reports on survey results asking people in different countries and income levels what is their bigger concern, high inflation or high unemployment. His main result is that, in his sample, poorer people are concerned more about high unemployment than high inflation, while richer respondents have the opposite preferences. Hence, concerns over employment and inflation probably have an important class dimension to them, something that economists and historians have suspected for many years.

Finally, is the issue of the role of IT in the context of supply shocks, which periodically affect individual economies and, as we have seen recently, the world economy as a whole, Rigid IT rules can prove highly

( problematic in the context of supply shocks, where the main problem facing countries is too little supply, not too much demand The solution is to help the economy absorb the loss of real income associated with the supply shock, without incurring collateral damage associated with greater income loss than absolutely necessary, while at the same time making the investments necessary to increase the supply of the key commodities or find substitutes for them over the medium term. Contractionary monetary policy is a decidedly highly inefficient tool for carrying out this complex task. This problem is exacerbated by rigid inflation targets and is only slightly ameliorated by the use of 'core inflation' indices which usually ostensibly exclude the first round costs of volatile energy and food prices. This is only a partial solution because in the medium term the increased costs of key commodities must filter their way through the input output structure and, even without real wage resistance on the part of workers which the central banks are presumably concerned with, will raise the core inflation rate temporarily. Hence, rigid adherence to IT in this context will lead to possibly large unnecessary costs in slower economic growth and income.

An overall picture on the selected macroeconomic indicators of the inflation targeters can be obtained from Tables 1.2 and 1.3. In Table I. 2 we provide information on the observed behavior of selected macro aggregates as the annual average of live years before the adoption of the IT versus the annual average af ter the adoption date to the current period. 
Table 1.3 keeps the same calendar frames and reports data on key macro prices, vir. the exchange rate and the interest rates.

Evidence on the growth performance of the IT countries is mixed. Taking the numbers of Table 1.2 at face value, we see that seven of the 21 countries report a decline in the average annual rate of real growth, whils three countries (Canada, Hungary and Thailand) have not experienced much of a shift in their rates of growth. Yet clearly it is quite hard to disentangle the eflects of the IT regime from other direct and indirect effects on growth. One such factor is the recent financial glut in the global asset markets and the associated surge of the household deficit spending bubble, which is now bursting. The Institute of International Finance data reveal, for instance, that the net capital inflows to the developing economics as a whole has increased from $\$ 47$ billion in 1998 , to almost $\$ 400$ billion in 2006, surpassing their peak before the Asian crisis of 1997. As the excessive capital accumulation in telecommunications and the dot.com high tech industries phased out in late 1990s, the global financial markets seem to have entered another phase of expansion, and external eflects such as these make it hard to isolate the growth impacts of the IT regimes.

Despite the inconclusive verdict on the growth front, the figures on unemployment indicate a significant increase in the post-IT cra. Only three countries on our list (Chile, Mexico and Switzerland) report a modest decline in their rates of unemployment in comparison to the pre-IT averages. The deterioration of employment perlormance is especially pronounced (and puzzling) in countries such as the Philippines, Peru and Turkey where rapid growth rates were attained. The increased severity of unemployment at the global scale seems to have affected the IT countries equally strongly, and the theoretical expectation that 'price stability would bring growth and employment in the long run' seems quite far from materializing yet.

The adjustment patterns on the balance of foreign trade have been equally diverse. Ten of the 21 countries in Table 1.2 achieved higher (improved) trade surpluses (balances). While there have been large deficit countries, such as Turkey, Mexico, the Philippines and Australia, there were also sizable surplus generators such as Brazil, Korea, Thailand, Canada and Sweden. Not surprisingly much of the behavior of the trade balance could be explained by the extent of over-valuation of the exchange rates, This information is tabulated in Table 1.3.

Táble 1.3, like Table 1.2, calculates the annual averages of the live-year period betore the IT versus annual averages after IT to date. Focusing on the inflation-adjusted real exchange rate movements, we find a general tendency towards appreciated currencies in the aftermath of adoption of the IT regimes. Mexico, Indonesia, Korea and Turkey are the most significant currency appreciating countries, while Brazil, and to some 
Table 1.2 Selected macroeconomic aggregates in the inflation targeting countriess

Before: Annual average of 5 years prior to adoption of IT: After : Annual average of adoption of IT to current

\begin{tabular}{|c|c|c|c|c|c|c|c|c|c|}
\hline & \multirow[b]{2}{*}{$\begin{array}{l}\text { Year IT } \\
\text { started }\end{array}$} & \multicolumn{2}{|c|}{$\begin{array}{l}\text { Growth } \\
\text { rate }\end{array}$} & \multicolumn{2}{|c|}{$\begin{array}{l}\text { Uneniploy- } \\
\text { ment rate }\end{array}$} & \multicolumn{2}{|c|}{$\begin{array}{l}\text { Frade Balance } \\
\text { (external } \\
\text { lbalance on } \\
\text { goods and } \\
\text { services) } \\
\text { /GDP ("\%) }\end{array}$} & \multicolumn{2}{|c|}{$\begin{array}{l}\text { Central bank } \\
\text { forcign rescrves } \\
\text { (US\$ Milliou) }\end{array}$} \\
\hline & & Before & After & Before & After & Before & After & Before & After \\
\hline New Zcalland & (9)() & 2.7 & 3.0 & 47 & 6.9 & 0.4 & 1.3 & 2897.9) & 4623.2 \\
\hline $\begin{array}{l}\text { Canada } \\
\text { United }\end{array}$ & |9)| & 20 & 2 & & 8.7 & 0.5 & 2.7 & 11964.0 & 24256.0 \\
\hline Kingdom & (1)(9) & 2.2 & 2.7 & 7.4 & 5.2 & 2.5 & -1.6 & 39666.5 & 37408.5 \\
\hline Sweden & ร9) 3 & 0.8 & 2. & & 6.1 & 1.3 & 6.2 & 15399.0 & 18521.8 \\
\hline Australial & 10) 4 & 2.2 & 3.9 & 8 & 7.3 & -0.6 & -1.3 & 13777.9) & 20337.1 \\
\hline Isracl & 1997 & 5.8 & 3.1 & 8.5 & 9.4 & -14.6 & -7.2 & 7567.3 & 24421.1 \\
\hline Czech Rep," & 19)98 & 4.5 & 3.2 & 4.0 & 8.9 & -3.4 & -1.8 & 9172.5 & 21686.5 \\
\hline Poland & 1998 & 7.9 & 3.7 & 14.3 & 16.7 & 0.0 & 4.1 & 12591.8 & 31581.8 \\
\hline Brazil & 19)() & 3.2 & 2.3 & 7.0 & 9.8 & -1.7 & 1.0 & 47701.3 & 42304.5 \\
\hline Colombial & (9)9) & 3.3 & 2.3 & 11.1 & 15.8 & -6.0 & 0.5 & 7567.3 & 24421.1 \\
\hline Mexico & (9)9) & 1.7 & 4.8 & 2.7 & 1.9 & 0.5 & -1.9 & 20630.9 & 51396.6 \\
\hline South Alrica" & 2000 & 26 & 3.8 & 11.a & 27.7 & 0.0 & 0.0 & 15860.0 & 9580.0 \\
\hline Swilzerland & 2000 & 1.4 & 1.7 & 4.1 & 3.1 & 0.1 & 0.1 & 38277.1 & 40646.5 \\
\hline Thailand & 2000 & 1.5 & 1.7 & 3.9) & 2.4 & 0.0 & 0.1 & 32556.1 & 40474.8 \\
\hline Korca & 2001 & 4.6 & 4.5 & 4.4 & 3.7 & 0.0 & 0.0 & 55299.5 & 157739.2 \\
\hline Hungary & 2001 & 4.2 & 4.2 & 8.0 & 6.1 & -1.3 & 2.9) & 99)18.1 & 13652.1 \\
\hline Peru" & 2002 & 2.0 & 5.2 & 7.8 & 10.2 & -3.2 & -0.4 & 9264.8 & 11222.9 \\
\hline Philippines & 2002 & 3.1 & 5.1 & 10.2 & 11.5 & -3.6 & -0.7 & 11281.6 & 14006.6 \\
\hline Indonesia & 2005 & 4.6 & 5.6 & 6.5 & 10.3 & 7.3 & 4.6 & 31326.7 & 32989.2 \\
\hline Turkcye & 2006 & 4.5 & 7.8 & 9.9 & 10.4 & -9.8 & 11.0 & 33237.4 & 56990.4 \\
\hline Turkeye & $2001 Q 2$ & 4.0 & 4.5 & 6.6 & 10.0 & 7.5 & 9.8 & 20083.4 & 33237.4 \\
\hline
\end{tabular}

Nores:

a. The period before the inflation targeting refer: to the period of 199) 4 97/or 'Growth' and 'CPI inflation' for the C\%ch Republic.

b. The period before the inllation largeting relers to the period of 1996 98 loor reserves in Bricil.

c. The period belore the inflation targeting refers to the period of 1994-9) 7 and al ter inflattion targeting refers to the period of 19992-2004 lor unemployment ralte in South Alrical. Note that due to change in methodology and data coverage, uncmployment ligures are not direcily comparable betore ant. al fer apartheid.

d. The period all ter the inflation target ing relers 10 the period of 2003 (04 ior uncmployment ralte in Peru.

c. Ollicial adoption date lor Turkey is 2006 . However, Turkish ecintral bank declared alisguised inllation targeling' in the al termath of the 200) F February erisis.

Sintre: $\quad$ IMF (2008). 
Table 1.3 Macroeconomic prices in the inflation targeting countries

Before: Ammual average of 5 years prior to adoption of it: Afier: Annual average of adoption of IT to current

\begin{tabular}{|c|c|c|c|c|c|c|c|c|c|}
\hline & \multirow[b]{2}{*}{$\begin{array}{l}\text { Year IT } \\
\text { started }\end{array}$} & \multicolumn{2}{|c|}{ 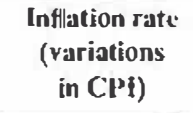 } & \multicolumn{2}{|c|}{$\begin{array}{l}\text { lexchange } \\
\text { rate real } \\
\text { deprcciationg," }\end{array}$} & \multicolumn{2}{|c|}{$\begin{array}{l}\text { CB real } \\
\text { interest } \\
\text { rate }\end{array}$} & \multicolumn{2}{|c|}{$\begin{array}{c}\text { Public } \\
\text { assets real } \\
\text { interest rate }\end{array}$} \\
\hline & & Before & After & Berore & After & Before & After & Before & After \\
\hline New Zealand & 1990 & 11.6 & 2.2 & -7.6 & 0.6 & 7.0 & 5.5 & 2.1 & 5.1 \\
\hline Chiles & 1991 & 19.7 & 7.2 & -6.0 & -4.0 & & 0.0 & 16.0 & -4.6 \\
\hline Cannada & 1991 & 4.5 & 2.1 & 7.5 & -1.7 & 6.0 & 2.6 & 5.8 & 2.5 \\
\hline \multicolumn{10}{|l|}{ United } \\
\hline Kingdom & 1992 & 6.4 & 2.6 & 2.4 & 2.2 & 5.4 & 3.0 & 5.0 & 2.8 \\
\hline Sweden & 1993 & 6.9 & 1.5 & 8.5 & 1.2 & 2.8 & 1.7 & 5.0 & 2.9 \\
\hline Australlial" & 1994 & 4.2 & 2.5 & -6.9 & -1.1 & 7.1 & 3.2 & 6.3 & 4.0 \\
\hline Isracl & 1997 & 11.3 & 3.1 & -4.2 & 0.9 & 2.0 & 5.0 & 1.5 & 5.0 \\
\hline \multicolumn{10}{|l|}{ Cerech } \\
\hline Republič & 1998 & 9.1 & 3.1 & -6.6 & -6.2 & 1.9 & 0.7 & 0.0 & 0.9 \\
\hline Polandu" & 1998 & 24.1 & 4.7 & 4.5 & .4 .6 & 1.6 & 6.2 & 1.8 & 11.6 \\
\hline Brazil & 1999 & 819.2 & 7.9 & -428.0 & 5.5 & -782.6 & 15.7 & -786.9 & 12.4 \\
\hline Colombia & 1999 & 20.4 & 7.5 & 9.5 & 0.5 & 18.4 & 6.6 & 1.5 & 2.0 \\
\hline Mexico & 1999 & 24.5 & 7.2 & 2.8 & 4.6 & 7.5 & 5.0 & 3.2 & 3.8 \\
\hline Thailand & 2000 & 5.1 & 2.2 & 4.5 & -1.0 & 4.9 & 1.6 & 4.7 & 3.1 \\
\hline South Africa" & $200 !)$ & 7.3 & 5.1 & 4.3 & 2.5 & 8.6 & 4.4 & 7.3 & 4.2 \\
\hline Switzerland & 2000 & 0.8 & 1.0 & 1.6 & -3.7 & 0.2 & 0.1 & 0.9 & 0.3 \\
\hline Koreal & 2001 & 4.0 & 3.3 & 6.0 & -5.0 & 0.2 & -1.0 & 6.5 & 2.1 \\
\hline Hungary & 2001 & 15.2 & 5.9 & 2.5 & 12.4 & 2.0 & 3.4 & 2.3 & 3.4 \\
\hline Peru & 2002 & 5.0 & 1.9 & -1.6 & 1.4 & 9.3 & 2.0 & 3.8 & 0.5 \\
\hline Philippines & 2002 & 6.3 & 5.0 & 8.7 & 3.0 & 5.1 & 0.9 & 5.2 & 1.2 \\
\hline Indonesia & 2005 & 8.0 & 10.5 & 6.2 & .1 .9 & 4.2 & 2.3 & 4.1 & 2.4 \\
\hline Turkey' & 2006 & 28.3 & 10.5 & -6.3 & -1.2 & 11.7 & 7.5 & 14.8 & 10.5 \\
\hline Turkeyr & 2001Q2 & 74.1 & 28.3 & 9.9 & -6.3 & -13.3 & 12.7 & 23.9 & 15.5 \\
\hline
\end{tabular}

Note:

a. The period after the inflation largeting period refers to the period of 199:3-2005; the period before the infation targeting refers to the period of 1987.90.

b. Treasury 13ill: the period alter the inflation largeting refers to the period of 1994 2000; CB Rate: the period allier the inllation targeting relers to the period of 1994.95 .

c. The period befise the inllation largeting reters to (he period of 199)4.97.

d. Treasury Bill rates; the period after the inllation targeting relers to the period of 19982000 .

c. Treasury Bill: the period belore the inflation targeting relers to the period of 1994 2000.

Ollicial adoption date for Turkey is 2006. However. Turkish eentral balnk declared disguised inllation targeting' in the alltermath of the 2001 February crisis.

g. A rise in value indicales deprecialtion. Annual average market rate is used for: UK, Calnada, Turkey, Australial, New Zealand, Brazil, Peru, Isracl, lndonesia, Korea and Philippines. Annual average Ollicial Rate is used for: Colombia, Thailand, Hungary, Poland and Switzerland. Principle rate is used For: South Africa, Mexico and Czech Republic. 
Table l.3 (continued)

1. Nominal values atre dellated by the corresponding inllation averages (CPl column).

i. Sweden. New Zealand, Canladal Bank Ralte; Mexico: Banker's Acceplante.

j. Colombia: Interbankantia TBS: Peru and Chile: Saving Rale: New Lealand Newly issued three montlos Trealsury bill ralles: Indonesiat: lhree Months Deposil Ralte: Korea: National flousing l3ond Rate: Thailand: (jovermment loond Yield Ratte.

Sestres: IMI: (2008).

extent Columbia, have pursued active export promotion strategies and maintained real depreciation./The Czech Republic, Switzerland and

Hungary are observed to have experienced nominal currency appreciation, and Poland seems to have maintained an appreciating path for its real exchange rate.

Clearly much of this generalized trend towards appreciation can be explained by reference to the increased expansion of foreign capital inflows due to the global linancial glut mentioned above. With the IT central bankers announcing a 'no-action' stance against exchange ratc movements led by the 'markets', a period of expansion in the global asset markets has generated strong tendencies for currency appreciation. What is puzzling, however, is the rapid and very signilicant expansion in the forcign exchange reserves reported by the IT central banks/As reported in the last two columns of Table 1.2, foreign exchange reserves held at the central banks rose signilicantly in the aftermath ol the IT regimes. The rise of rescrves was especially pronounced in Korea, the Philippines and Israel where almost a five-fold increasc had bcen witnessed. Of all the countrics surveyed in Table 1.3, the UK and Brazil are the only two countries that had experienced a fall in their aggregate reserves. ${ }^{3}$

This phenomenon is puzzling because the well-celebrated 'flexibility' of the exchange rate regimes were advocated precisely with the argument that, under the IT framework. the central banks would gain freedom in their monetary policies and would no longer need to hold reserves to defend a targeted rate of exchange. In the absence of any officially stated exchange rate target, the need for holding such sums of foreign reserves at the central banks should have been minimal. The proponents of the IT regimes argue that the central banks need to hold reserves to 'maintain price stability against possible shocks'. Yet, the acclaimed 'defense of price stability' at the expense of such large and costly funds that are virtually kept idle at the IT central banks' reserves is questionable at best in an cral of prolonged unemployment and slow investment growt iy, and needs to be justilied economically as well as socially.

We now turn to the issue of exchange rate policy more formally. 


\subsection{THE ROLE OF THE EXCHANGE RATE UNDER INFLATION TARGETING}

As stated above, part of the broader recuirements surrounding the IT system is often argued to be the implementation of a 'floating/llexible' exchange ratc system in the context of free mobility of capital. Thus, 'exchange ratc flexibility and floating exchange rate system' became the new molto, and to many advocates, central bank 'policy' has typically been reduced to mean merely 'setting the policy interest rate'. The exchange rate and macro prices are, in theory at least, thereby left to the unfettered workings of the global finance markets. The role of the exchange rate as an adjustment variable has clearly increased over the last decade since the adoption of the floating exchange rate systems. In the meantime, however, the role of the interest rates and reserve movements has declined substantially as counter-cyclica! instruments available to be used against shocks ${ }^{*}$ (see Table 1.2).

Against this background a number of practical and conceptual questions are inevitable: what is the role of the exchange rate in the overall macroeconomic policy when an explicit IT regime is adopted? Under what conditions should the central bank, or any other authority, react to shocks in the foreign exchange market? And perhaps more importantly, if an intervention in the foreign exchange market is regarded necessary against, saly, the disruptive ellects of an external shock, what are the proper instruments?

To the proponents of IT, the answer to these questions is simple and straightlorward: the central bank should not have any objective in mind with regards to the level of the exchange rate, yet it might interfere against the volatility of the exchange rate in so far as it affects the stability of prices. However nuances remain. To what may be grouped under 'strict conformists', the central bank should be concerned with the exchange rate only if it affects its ability to forecast and target price inllation. Any other response to the foreign exchange market represents a departure from the IT system. Advocaled in the seminal works by Bernanke et al. (1999) and Fischer (2001), the approach argues that attending to IT and reacting to the exchange rate are mutually exclusive. Beyond this assertion, the conformist view also holds that intervention in the foreign exchange market could confuse the public regarding the ultimate objective of the central bank with respect to its priorities, distorting expectations. In a world of credibility game, such signals would be detrimental to the central bank's authority.

Yet, while maintaining the IT objective, one can also distill a more active role for the exchange rate in the literature. As outlined by Debelle 
(200t), this 'flexible IT' view proposes that the exchange rate can also be a legitimate policy objective alongside the inflation target. More formally, an operational framework for the 'flexible IT' view was envisaged within an expanded Taylor rule. thaylor (2000) argued, for instance, that an exchange rate policy rule cian legitimately be embedded in a Taylor rule that is consistent with the broad objectives of targeted inflation rate and the output gap.

In contrast to all this, the structuralist tradition asserts that irrespective of the conditionalities of foreign capital and boundarics of IT, it is very important for the developing cconomics to maintain a stable and competitive real exchange rate (SCRER) (see, for example, Cordero, Chapter 3, this volume; Frenkel and Taylor, Chapter 2, this volume; Galindo and Ros, Chapter 8, this volume; Frenkel and Ros, 2006; Frenkel and Rapetti, Chapter 9, this volume). They argue that the real exchange rate can alfiect employment, and the economy more generally, through a number of chamnels: (1) by affiecting the level of aggregate demand (the macroeconomic channel); (2) by aflecting the cost of labor relative to other goods and thereby alfecting the amount of labor hired per unit of output (the labor intensity channel); and (3) by alfecting employment through its impact on investment and economic growth (the development channel). While the size and even direction of these channel efrects might difficr from country to country/tinaintaining a competitive and stable real exchange rate is likely to have a positive employment impach hbrough some combination of these effiects.

The gist of the structuralist case for SCRER rests on a recent (and unfortunatcly not well understood or appreciated) paper by Taylor (2004). Resting his arguments on the system of social accounting identities, Taylor argucs that the exchange rate camnot be regarded as a simple 'price' determined by temporary macro equilibrium conditions. The mainstream casc for exchange rate detcrmination rests on the well-celebrated Mundell (1963) and Fleming (1962) model where the model rests on an assumed duality between reserves (fixed exchange rate system) versus flexible exchange ratc adjustments. The orthodox mainstream model, according to Taylor, presupposes that a balance of payments exists with a potential disecuilibrium that has to be cleared. This, however, is a false presumption. The exchange ratc is not an 'independent' price and has no fundamentals such as a given real rate of return (or a trade deficit) that can make it self-stabilizing. In Taylor's words, 'the balance of payments is at most an accumulation rule for net foreign assets and has no independent status as an equilibrium condition. The Mundell-Fleming duality is irrelcvant, and in temporary equilibrium, the exchange rate does not depend on how a country operates its monetary (especially international reserve) policy' (Taylor, 2004, p. 212). 
The preceding discussions clearly underscore that the real world bchavior of exchange rates is quite complex and the focus of the inflation targeting regime for floating exchange rates (in expectation of dropping it from the policy agenda allogether) is a mirage. This view of exchange rates helps to explain why many believe that there are no viable alternatives to IT as a mode of central bank policy. However, as this book tries to demonstrate, and as we brielly discuss in the next section, this view of no viable altematives to inflation targeting is not correct.

\subsection{SOCIALLY RESPONSIBLE ALTERNATIVES TO INFLATION TARGETING CENTRAL BANK POLICIES}

One reason that 'inflation-focused monetary policy' has gained so many adherents is the common perception that there is no viable alternative monetary policy that can improve growth and employment prospects. These arc two main factors accounting for this perception. First, as we discussed in the previous section, in an internationally financially integrated economy with high levels of international capital flows, monetary policy can bc exiremely challenging. In particular it might be very dillicult to gear monetary policy by targeting monetary aggregates, or by pegging an exchange rate along with trying to promote employment growth. This is often seen as the so-called 'trilemma' which commands that central banks can only have two out of threc of the following: open capital markets, a lixed exchange ratc system and an autonomous monctary policy geared toward domestic goals. While this so-called 'trilemma' is not strictly truc as a theoretical matter, in practice it does raise serious issucs of monetary management (see the above arguments cited from Taylor, 2004 and Frenkel and Taylor, 2006). From our perspective, the real crux of the problem turns out to be the very narrow interpretation of the constraints of the trilemma: central banks are often thought to be restricted to choose two 'points' out of three. Yet, the constraints of the trilemma could as wel! be regarded as the boundaries of a continuous set of policies, as would emerge out of a bounded, yet continuous depiction of a 'policy triangle'. Thus even within the boundaries of the trilemma a menu of choices does exist, sanging from administered exchange rate regimes to capital management/control technicues. In fact, many successl ul devcloping countries have used a variety of capital management technicjues to manage these flows in order, among other things, to help them escape the rigid constraints of the so-called 'tri-lemma' (Epstein ct al., 2005; Ocampo, 2002).

In this section we report on a series of country studies undertaken by a 
team of researchers working on a Political Economy Research Institute (PER1) (University of Massachusetts, Amherst)/Bilkent project on alternatives to inflation targeting, as well as a United Nations Development Programme (UNDP) sponsored study of employment targeting economic policy for South Africa. A range of alternatives were developed by the researchers, all the way from modest changes in the IT framework to allow for more focus on exchange rates and a change in the index of inllation used, to a much broader change in the overall mandate of the central bank to a focus on employment targeting, rather than IT. Some of the alternative policies focus exclusively on changes in central bank policy, while for other countries changes in the broad policy framework and in the interactions of monetary, financial and liscal policy are proposed. Some incorporate explicit goals and targets, white others prefer more llexibility and somewhat less transparency.

It has to be noted at the outset that 'inflation control' is revealed among the ultimate objectives in all country studics summarized below. Thus there is a clear consensus among the country authors that controlling inflation is important and desirable. However all agree that the current prescription insisting on 'very low' rates of inflation at the 2-4 percent band is not warranted, and that responsibilities of the central banks, particularly in developing countries, must be broader than that. Accordingly, the policy matrix of the central banks shculd include other crucial 'real' variables that have a direct impact on employment, poverty and economic growth, such as the real exchange rate and/or investment allocation. They also agree that in many cases, central banks must broaden their available policy tools to allow them to reach multiple goals, including, if necessary, the implementation of capital management techniques.

Table 1.4 presents al summary of the alternatives proposed in the PERI/ Bilkent project and is discussed further in what follows.

\subsubsection{Modest but Socially Responsible Adjustınents to the Inflation Targeting Regime}

Some of the country studies in the PERI/Bilkent proiject proposed only modest changes to the IT regime. In the case of Mexico, for example, the authors argue that the IT regime has allowed for more flexiblc monetary policy than had occurred under regimes with strict monetary targets or strict exchange rate targets (Galindo and Ros, Chapter 8, this volume). They suggest modifying the IT framework to make it somewhat more employment firiendly. In the case of Mexico, Galindo and Ros find that monetary policy was asymmetric with respect to exchange rate movements - tightening when exchange rates depreciated, but not loosening when 
Table 1.4 PERI/Bilkent alternatives to inflation targeting project, summar y of policy recommendations

\begin{tabular}{|c|c|c|c|c|c|}
\hline Country & L'Itimate targets & $\begin{array}{l}\text { Intermediate } \\
\text { targets }\end{array}$ & $\begin{array}{l}\text { Strict target } \\
\text { or discretion }\end{array}$ & Tools/instruments & $\begin{array}{l}\text { Central bank: } \\
\text { independent, } \\
\text { integrated or } \\
\text { coordinated? }\end{array}$ \\
\hline Argentina & $\begin{array}{l}\text { Inflation control. } \\
\text { activity level } \\
\text { and e mployment } \\
\text { expansion. external } \\
\text { sustainability }\end{array}$ & $\begin{array}{l}\text { SCRER. interest } \\
\text { rate }\end{array}$ & Discretion & $\begin{array}{l}\text { Sterilization, reserve } \\
\text { requir ements } \\
\text { (other prudential } \\
\text { requirements). } \\
\text { capital } \\
\text { management } \\
\text { techniques }\end{array}$ & Coordinated \\
\hline Brazil & $\begin{array}{l}\text { Inflation control. } \\
\text { export promotion, } \\
\text { investment expansion }\end{array}$ & SCRER & Discretion & $\begin{array}{l}\text { Inter est rate, } \\
\text { asymmetric } \\
\text { managed float } \\
\text { (moving floor on } \\
\text { exchange rate). } \\
\text { bank reserves. } \\
\text { bank capita! } \\
\text { requir ements, bank } \\
\text { capital } \\
\text { requir ements }\end{array}$ & $\begin{array}{l}\text { Integrated/ } \\
\text { coordinated with } \\
\text { the fiscal and anti- } \\
\text { poverty objectives }\end{array}$ \\
\hline India & $\begin{array}{l}\text { GDP growth. } \\
\text { inflation control. } \\
\text { export promotion }\end{array}$ & $\begin{array}{l}\text { Slightly undervalued } \\
\text { (competitive) } \\
\text { exchange rate }\end{array}$ & Discretion & $\begin{array}{l}\text { Interest rate. } \\
\text { capital } \\
\text { managemen } t \\
\text { techniques. if } \\
\text { necessary }\end{array}$ & Integrated \\
\hline
\end{tabular}


Table 1.4 (continued)

\begin{tabular}{|c|c|c|c|c|c|}
\hline Countrỵ & Ultimate targets & $\begin{array}{l}\text { Intermediate } \\
\text { targets }\end{array}$ & $\begin{array}{l}\text { Strict target } \\
\text { or discretion }\end{array}$ & Tools/instruments & $\begin{array}{l}\text { Central bark: } \\
\text { independent, } \\
\text { integrated or } \\
\text { coordinated? }\end{array}$ \\
\hline Mexico & Inflation. SCRER & $\begin{array}{l}\text { Implementation of } \\
\text { 'domestic' inflation } \\
\text { measure, SCRER, } \\
\text { 'sliding fioor' on } \\
\text { exchange rate }\end{array}$ & Discretion & $\begin{array}{l}\text { Capital management } \\
\text { techniques }\end{array}$ & Integrated \\
\hline South Africa & $\begin{array}{l}\text { Employment } \\
\text { generation, infiation } \\
\text { control }\end{array}$ & Real GDP growth & $\begin{array}{l}\text { Strict } \\
\text { employment } \\
\text { target } \\
\text { (coordinated } \\
\text { with other } \\
\text { institutions). } \\
\text { looser } \\
\text { inflation } \\
\text { constraint }\end{array}$ & $\begin{array}{l}\text { Interest rate: } \\
\text { cređit allocation } \\
\text { techniques (e.g. } \\
\text { asset-based reserve } \\
\text { requirements, loan } \\
\text { guarantees etc.). } \\
\text { capital management } \\
\text { techniques }\end{array}$ & Integrated \\
\hline Turkey & $\begin{array}{l}\text { Inflation control: } \\
\text { employment } \\
\text { generation: solvency } \\
\text { of public debt: } \\
\text { consolidate and } \\
\text { expand social } \\
\text { infrastructure }\end{array}$ & $\begin{array}{l}\text { Real interest rate, } \\
\text { non-appreciated } \\
\text { exchange rate }\end{array}$ & Discretion & $\begin{array}{l}\text { Capital management } \\
\text { techniques if } \\
\text { necessary. labor-tax } \\
\text { reform. increased } \\
\text { public investments } \\
\text { in social capital }\end{array}$ & $\begin{array}{l}\text { Integrated/ } \\
\text { coordinated } \\
\text { with the fiscal } \\
\text { and employment } \\
\text { objectives }\end{array}$ \\
\hline
\end{tabular}




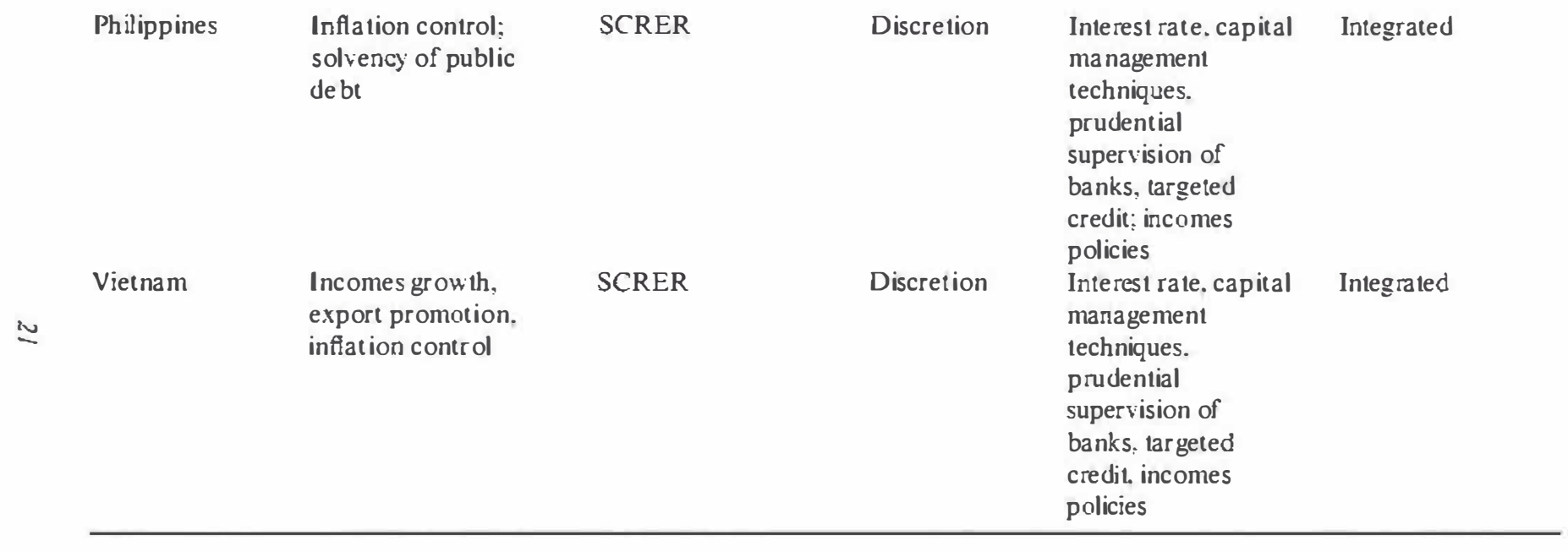

Note: SCRER: Stable and Competitive Real Exchange Rate; Central Banks: integrated means integrated into governmental macroeccnomic policy making framework: coordinated means independent but committed to close coordination with other macroeconomic policy making institutions.

Source: IMF (2008) 
exchange rates appreciated. This lent a bias in favor of an over-valued exchange rate in Mexic): So they propose a 'neutral' monetary policy so that the central bank of Mexico responds symmetrically to exchange rate movements and thereby avoids the bias towasd over-valuation without fundamentally changing the IT framework. In their own words, "the central bank would promote a competitive exchange rate by establishing a sliding floor to the exchange rate in order to prevent excessive appreciation (an "asymmetric band". . .). This would imply intervening in the for eign exchange market at times when the exchange rate hits the floor (i.e. an appreciated exchange rate) but allows the exchange rate to that freely otherwise'. They point out that such a tloor would work against excessive capital inflows by speculators because they would know the central bank will intervene to stop excessive appreciation. If need be, Galindo and Ros also propose temporary capital controls, as do some of the other authors from the PERI/Bilkent project.

In his study of Brazil Nelson Barbosa-Filho 2008 Chapter 7, (this volume) also proposed extending the IT framework, but in a more dramatic way. According to Barbosa-Filho: 'because of Brazil's past experience with high infation, the best policy is to continue to target inflation while the economy moves to a more stable macroeconomic situation. However, the crucial question is not to eliminate inflation targeting, but actually make it compatible with last income growth and a stable public and foreign finance'.

Given Brazil's large publịc debt, Barbosa-Filho proposes that the targeted reduction in the real interest rate would reduce the Brazilian debt service burdens and help increase productive investment. In terms of the familiar targets and instruments framework, he proposes that the Brazitian central bank choose exports, inllation and investment as ultimate targets, and focus on the inflation rate, a competitive and stable real exchange rate and the real interest tate as intermediate targets. Furthermore, in order to achieve these goals, the central bank can use direct manipulation of the policy interest rate, bank reserve requirements and bank capital requirements.

Brazil is not the only highly indebted country in our project sample. Turkey is another case with that problem. Here too the authors raise concerns to the conformist straightjacket of IT, and develop an alternative macroeconomic framework. Using a financial-linked computable general equilibrium model (CGE) for the case of Turkey, Telli et al. (Chapter 10 , this volume) illustrate the real and financial sectorial adjustments of the Turkish economy under the conditionalities of the twin targets: on primary surplus to GNP ratio and on the inflation rate. They utilize their model to study the impact of a shift in policy from a strict IT regime, to 
one that calls for revisions of the primary fiscal surplus targets in favor of a more relaxed liscal stance on public investments on social capital, together with a direct focus on the competitiveness of the real cxchange rate. They further study the macroeconomics of a labor tax reform implemented through reduction of the payroll tax burden on the producers, and an active monetary policy stance via reduction of the central bank's interest rates. They report significant employment gains due to a policy of lower cmployment taxes. They also find that the cconomy's response to the reduction of the central bank's interest rate is positive in general; yet very much dependent on the path of the real exchange ratc, thus they also call for maintaining a stable real exchange rate path à la Frenkel, Ros and Taylor.

Frenkel and Rapetti (Chapter 9, this volume), in the case of Argentina, show that targeting a stable and competitive real cxchange rate has been very successful in helping to maintain more rapid economic growth and employment generation. In the case of India, Jha (Chapter 12, this volume) also argues against an IT regime, and in favor of one that 'errs on the side of undervaluation of the exchange rate' with possible help from temporary resort to capital controls. Jha argues that, to some extent, such a policy would be a simple continuation of policies undertaken in India in the past. In Vietnam Packard concludes: 'a strict inflation targeting regime is not appropriate for Vietnam. Inflation targeting's rigid rules constrain policy makers to operate in a framework that requires inflation to take priority over more pressing development objectives. Thus, a stable and competitive real exchange rate is a superior afternative, precisely becaluse it sets as a target a key macroeconomic relative price that is realistic, sustainable and growth enhancing' (Packard, Chapter 14, this volumc).

\subsubsection{More Comprehensive Alternatives to Inflation T'argeting}

Other country case studies propose more comprehensive policy alternatives to simple inflation-focused monetary policy, including IT. Joseph Lim (Chapter 13, this volume) proposes a comprehensive altcrnative to IT for the case of the Philippines. He argues that the Philippines' government has been seeking to achieve a record of dramatically higher economic growth, but that its monetary policy has been inadequate to achieving that goal. He therefore proposes an 'alternative' that 'clcarly dictates much more than just a move from monetary targeting to inflation targeting' with the following proposals: (I) Maintenance of a competitive real exchange rate, either by pegging the exchange rate or intensively managing it as in South Korea. (2) Implementation of capital management techniciues, as in China and Malaysia, to help manage the exchange rates. This should 
include strong financial supervision to prevent excessive undertaking of short-term foreign debt, and tax based capital controls on short-term capital fows, as was used, for example in Chile. (3) An explicit statement of output and employment goals, as the central bank transits from a purely IT regime. (4) Incomes and anti-monopoly policies to limit inflation to moderate levels. (5) Targeted credit programs, especially for export oriented and small and medium sized enterprises that can contribute to productivity growth and employment.

These policy proposals in broad outlines are similar to those proposed by Epstein (Chapter 11, this volume) for the case of South Africa, which, in turn, have been developed in a much broader framework and in more detail by Pollin et al. (2006). Pollin et al. developed an 'employmenttargeted economic program' designed to accomplish this goal, with a focus on monetary policy, credit policy, capital management techniques, fiscal policy and industrial policy. The purpose of the program is to reduce unemployment rate by half in line with the government's pledge to reduce the official unemployment rate to 13 percent by $2014 .{ }^{5}$ Here, 'employment targeting' replaces IT as the proposed operating principle behind central bank policy, and moderate inflation becomes an additional formal constraint which the central bank must take into account when formulating its policies.

\subsection{CONCLUDING COMMENTS}

In this introductory chapter we have argued that the current day orthodoxy of central banking - namely, that the top priority goal for central banks is to keep inflation in the low single digits - is, in general, neither optimal nor desirable This orthodoxy is based on several false premises: first, that inflation, in any magnitude, has high costs; second, that in a low inflation environment economies will naturally perform best, and in particular, will generate high levels of economic growth and employment; and third, that there are no viable alternatives to this 'inflation-focused' monetary policy.

In fact, moderate rates of inflation episodes reveal to have very low or no costs; and whether countries where central banks have adopted formal or informal IT have not performed better in terms of economic growth or employment generation is a matter of dispute. Per contra, there are viable alternatives to IT, historically, currently, and looking forward.

Historically, countries both in the currently developed and developing worlds had central banks with multiple goals and tools, and pursued broad developmental as well as stabilization goals. Currently, very 
successful economies such as Argentina, China and India have central banks that are using a broad array of toois to manage their economies for developmental purposes. And looking forward, the PERI/Bitkent project on alternatives to IT and PERI's UNDP work on South Africa have developed an array of 'real targeting' approaches to central banking which we believe are viable alternatives to IT and, in particular, do a better job than mere IT in balancing the developmental and stabilization functions of central banks.

\section{NOTES}

1. We arc indebted to Hasan Comert, Luis Rosero and Lynda Pickbourn for their diligent research assistance, and to Roberto Frenkel. Jose Antonio Ocampo, K.S. jomo, Geoflirey Woglom, Refel Gïrkalynalk, James Heintz, Leonce Ndikumanal. Arjun Jayadev and Robert Pollin for their valuable comments and suggestions on previous versions of the chapter. Research for this chaptet was completed when Yeldain was a

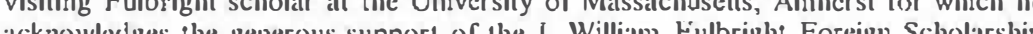
acknowledges the generous support of the s. Willan fubright Foreign Scholarship Board and he hospitality of he Political Economy Research lnsticte at he University of Malssachusells. Anherst. We are also grateful to the funders of the PERI/Bilkent Alternatives to Inflation Targeting project. including UN.DESA, Ford Foundation, Rockeleller Brothers Fund and PERI lior their support. Needless to mention, the views expressed in the chapter are solely those of the authors and do not implicalte in any way the institutions mentioned above.

2. Note that with the use of the term 'conditionality" here we refer not to the IMF's standby rules in the narrow sense of balance of payments stabitizaltion, but to the broalder se of relorms and structural adjustment agenda as advociated by the international finance commenity and the transnational corporations. Often dubbed as the (post.) Washington consensus, the warranted set of policies range from IT central banks and flexible lorejgn exchange markets to broader institutional relorms such as Ilexible labor markets, privitization and increased governance. See Williamson (1993) for the original deployment of the term, and Rodrik (2003) lor further discussion.

3. Braigil's calse is actually explained in part by the recent decision (late 2005) of the Lula bovernment 10 close its debt arrears with the IMF with early payments out of its reserves.

4. Though note the one sided ever increalse in the aggregatc reserves of the central banks The social desirability and economic optimality of this phenomenon in the aftermath of the adoption of floating exchange rate systems is another issue that warrants further

5. As of March 2005, South Alirica had an unemployment ralte of anywhere from 26 percent 1040 percent, depending on exactly how it is counted.

\section{REFERENCES}

Adelman, I. and E. Yeldan (2000), 'The minimal conditions for a financial crisis: a multi-regional inter-temporal CGE model of the Asian crisis', Wortd Derelopmem, 28 (6), 1087100. 
Akyuz, Y. (2003), The Denceloping C'oumeries and World Trate. Perfonrmance and Prospects, London: ZED Books.

Akyuz, Y. (2006), 'From liberalization to investment and jobs: lost in translation, paper presented at the Carnegie Endowment lor International Peace Conference, 14-15 April 2005, Washing ton, DC, pp. 45 6.

Akyuz, Y., H. Flassback and R. Kozul-Wrighe (2006), 'Globalization, inequality and the labour markct', in A. Kose, F. Scnscs and E. Ycldan (eds), Neoliberal Gibbalizarium a.s New Imperialism: C'ase Studies' on Recomstraction of the Periphery. New York: NOVA Science.

(Ball, L. and N. Sheridan (2003), 'Docs inllation targeting matter?', International Monetary Fund working paper no. 03/129.

Batini, N., P. Breuer, K. Kochhar and S. Roger (2006), Inflation targeting and the IMF' International Monetary Fund stall paper, Washington, DC, March.

Bernanke, B.S., T. Laubach, A.S. Posen and F.S. Mishkin (1999), Inflation Targeting: Lessomss fiom the Internatiomal Experience, Princeton, NJ: Princeton University Press

Buiter, W. (2006), 'Rcthinking inllation targeting and central bank independence', paper presented at the Turkish Economic Association Conferencc, Ankara, September.

Corbo, V., Landerretche and K. Schmidt-Hebbel (2001), 'Does inllation target ing make a difficrence'? Central Bank of Chile working paper no. 106, accessed 15 January 2007 al www. bcentral.cl/Estudios/DTBC/doctrab.htm.

Debelle, G. (2001), 'The calse lor inflation targeting in East Asian countrics', in Future Directions: far Mometary Policies in East Asia, Sydney: Reserve Bank of Australia, pp. 65-87.

Edwards, S. (2005), 'The relationship between exchange rates and inflation targeting revisited', National Bureau of Economic Research, working paper no. W 12163.

Epstein, G., 1. Grabet and K.S. Jomo (2005). 'Capital management techniques in devdoping countries: an assessment of experiences from the 1990s and lessons for the future', in Gerald Epstein (ed.), Capital Filight and Capital C'omtrols in Developing Commerices. Chelt enham, UK and Northampton, MA, USA: Edward Elgar, pp. 301-33.

Feldstein, M. (1997), 'Capital income taxes and the benelits of price stability', National Bur eau of Economic Research working paper no. 6200, September.

Fischer, S. (2001), 'D istinguished lecture on economics in government', Journal of Ecomomic Perspectives, 15 (2), 3-24.

Fleming, J. Marcus (1962), 'Domestic financial policies under lixed and under flexible exchange rates', International Monet ary Fund stalf papers 9, p. 369-79.

Freeman, R. (2004), 'Doubling the global workf'orce: the challenges of' intcgrating China, India, and the former Soviet Bloc into the world economy', paper presented at the conference on 'Doubling the Global Work Force', Institute of International Ecomomics, 8 November, Washington, DC.

Freeman, Richard B. (2007), 'The greal doubling: is your job going to Bombay or Beijing?', in America Work.s; Critical Thoughts an the' Exceptromal US Labor Marke, New York: Russell Sage Foundation, pp. 128-40.

Frenkd, R. and J. Ros (2006), 'Unemploy ment and the real cxchange rate in Latin America', H'orld Development, 34(4), 63i-46.

Frenkel, R. and L. Taylor (2008), 'Real exchange rate, monetary policy, and 
employment', United Nations Department of Economic and Social Alrairs (DESA) work ing palper no 19, February, New York.

Heintz, J. (2006), 'Globalization, economic policy and cmployment: poverty and gender implications', Employment Strategy Department employment strategy pa per 2006/3, International Labour Organization, Geneva.

International Labour Organization ([LO) (2004), Global Emplojement Tremels 20)(14 Geneva: ILO.

International Monetary Fund (IMF) (2008) Imernational Fincuncial Sicutistics, CD Rom, Washington, DC: IMF

Michl, Thomas (2007), 'T inber gen rules the Taylor rule', Levy Economics Institute working palper no. 444.

Mishkin, F.S. and K. Schmidt-He bbel (200I), 'One decale of inf lation tar geting in the world: what do we know and what do we need to know?', National Bureal of Economic Research working paper no 8397, July accessed al www.nber. org/ papers/w8397.

Mundell, R.A. (1963), 'Capital mobility and stabilization poticy under lixed and flexible exchange rates', C'ancelicun Journal of Economics and Political Scicince, 29, 475-85.

Ocampo, J. A. (2002), 'Ca pitataccount and counter-cyclical prudential regulations in de veloping countries', Workd Institu te for Development Economics Research discussion palper, Augus 1 .

Pollin, R. and A. Zhu (2006), 'Inflation and economic growth: a cross-country nonlinear analysis', Jousmal of' Post Kejencesican Ecomomics, 28 (4) (Summer), $593-614$.

Pollin, R., G. Epste in, J. Heintz and L. Ndikumana (2006), An Emplo ynnem-Targereed Economic Progrcam for South Africa, Cheltenham. UK and Northampton, MA, USA: Edward Elgar.

Rodrick, D. (2003), 'Growth strategics', National Bureau of Economic Research working paper no. 10050 .

Roger, S. and M. Stone (2005), 'On target? The international experience with achieving inflation targets', International Monetary Fund working paper WP/05/163, Washington, DC

Seltertield, M. (2006), 'Is inflation targeting compatible with post keynesian economics?', Journal of Post Keynesicun Ecomomics, 28 (4), 653-7I.

Taylor, J.B. (2000), 'Low infliation, pass-through and the pricing power of firıns', Europecul Ecomomic Review, 7 (44), 1389-408.

Taylor, L. (2004), 'Exchange rate indeterminacy in portfolio balance, MundellFleming and uncovered interest parity models', C'amhriclge Journal of Ec'omemic.s, 28, 205-27.

Tobin, J. (1980), 'Stabilization policy ten years after'. Brookings: Papers an Ecomomic Activity, I, 19.71.

Williamson, J. (1993), 'Democracy and the Washington Consensus', Worlel Developine'in, 21 (8), 1329-36. 